\title{
EXPERIMENTAL INVESTIGATION ON TRIPLE BLENDED SCC FILLED STEEL TUBES WITH AND WITHOUT STIFFENERS
}

\author{
Naveen Kumar Y R $\mathbf{R}^{1}$, Sharada $S \mathbf{A}^{2}$, G Narayana ${ }^{3}$ \\ ${ }^{l}$ Master of Technology (Structural Engineering) Student, Civil Department, S J C Institute of Technology, \\ Chickballapur, Karnataka, India, \\ ${ }^{2}$ Assistant Professor, Civil Department, S J C Institute of Technology, Chickballapur, Karnataka, India, \\ ${ }^{3}$ Professor \& Head of Civil Engineering Department, S J C Institute of Technology, Chickballapur, Karnataka, India.
}

\begin{abstract}
Concrete filled steel tubular columns are gaining its popularity in engineering practice. However, local buckling is the main criteria which effects on strength and ductility for the composite columns. In order to enhance their overall performance, one of the most effective measures is to provide stiffeners for the steel tubes. In the present research, experimental studies have been devoted to investigating the behavior of self-compacting Concrete Filled Steel Tube (CFST) stub columns strengthened by single or double stiffeners. A total of 36 stub columns specimen under monotonic compression load were tested in order to discover the best configuration of column system where (specimen having zero stiffeners, single stiffener, double stiffeners) each for hollow steel and with SCC in-filled are tested for 7 days, 28 days and 56 days strength with circular cross-sections of dimensions $300 m m$ height $x 100 \mathrm{~mm}$ diameter $x 2 \mathrm{~mm}$ thickness. The experimental results indicated that the use of Stiffeners strengthen the CFST has a significant effect on the overall behavior of CFST such as enhancement on its strength and ductility. Also the Stiffeners confinement delays local buckling of steel tube, prevents a sudden strength reduction caused by the local buckling of the steel tube, and increases lateral confinement of the concrete core. It is found that the best configuration of Stiffeners in the Steel tubes is providing it in transverse direction with single and double stiffeners at a height of $h / 2$ and h/3 respectively.
\end{abstract}

Keywords: Composite Columns, Concrete Filled Steel Tube, Stiffeners, Self Compact Concrete etc.,

****

\section{INTRODUCTION}

Concrete Filled Steel Tubes (CFST) is a composite component where concrete is utilized to fill in the steel tubes. At this present day it is broadly known that application of more than two materials in a structure specially can give raise to an efficient system in order to resist seismic forces. Use of such composite structural member has been tremendously increased all over the world during these past few years.

Composite column members are very important application in the field of composite constructions. Application of composite column members can result in savings of dimension of column, which leads to the economic savings in structure construction. The minimization in column dimension provides substantial benefits such as larger floor area like in car parks and office blocks. Also in slender column members, where severe buckling will occur, the steel tube will provide significantly to the strength. The steel casing confines the concrete core and filled concrete inhibits local buckling of the steel tubes which is the main reason for the member to carry maximum load.

CFST members are basically suited for varieties of applications because of their effective using of construction material. These composite elements are capable of carrying large amount of axial load and widely used because of its high stiffness, high ductility, large capacity of energy absorption and high strength.
Circular steel tube sections poses a benefit compared to different sections when they are used as compression member. Consider a particular cross sectional, they have a large uniform elastic stiffness about every direction and by filling the empty steel tubes with concrete build an effective definitive strength of the part with vey less noteworthy increment of expense. The main reason of filling concrete in steel tubes is because it can postpone the local buckling of outer casing of CFST i.e., steel tube and concrete core will also be in a controlled manner, and it has the capacity to withstand greater stresses and strains than when the segment is uncontrolled.

\section{METHODOLOGY}

The following specimens are tested using compressive testing machine of $2000 \mathrm{KN}$ capacity in order to determine buckling load, rupture load and deformation for a same section specimens by varying the stiffeners and stiffeners providing height. The specimens given below are for testing at 7days, 28days and 56 days respectively as given below. The steel tubes sections were cut from the original $6 \mathrm{~m}$ steel tube and the ends were mounded according to dimensions using cutting machine. The inside of the steel tubes are brushed using metal wires to remove any rust and loose debris. The deposits such as any grease and oil were removed away too. One end of the tube was sealed by plates in order to prevent any seepage during concrete pouring, and then the tubes were placed upright with the sealed end on a leveled white board to ensure stability during concrete pouring. 
Total 36 specimens were casted by filling self-compacting concrete in prepared steel tubes. The concrete filled kept away from any vibration to ensure self-compacting.
The models were placed upright to air-dry, and all loose mortar was removed from the top surface of the hardened concrete after 1 day, then the curing of CFST was done by covering the specimen with gunny bags, after wetting the top surface in order to avoid development of cracks and shrinkage in concrete.

Table 1: Number of specimens casted

\begin{tabular}{|c|c|c|c|c|c|c|c|c|c|}
\hline \multirow{3}{*}{ Specimens } & \multicolumn{3}{|c|}{$\begin{array}{l}\text { without } \\
\text { stiffener }\end{array}$} & \multicolumn{3}{|c|}{$\begin{array}{l}\text { single } \\
\text { stiffener }\end{array}$} & \multicolumn{3}{|c|}{$\begin{array}{l}\text { double } \\
\text { stiffeners }\end{array}$} \\
\hline & 7 & 28 & 56 & 7 & 28 & 56 & 7 & 28 & 56 \\
\hline & \multicolumn{9}{|c|}{ days } \\
\hline Hollow steel tubes in no's & \multicolumn{3}{|l|}{3} & \multicolumn{3}{|l|}{3} & \multicolumn{3}{|l|}{3} \\
\hline Triple blended SCC filled steel tubes in no's & 3 & 3 & 3 & 3 & 3 & 3 & 3 & 3 & 3 \\
\hline
\end{tabular}

\section{STIFFENERS}

Stiffeners are the structural members used to delay the buckling of column by increasing its strength. In this experiment, investigation is done by proving a single stiffener at mid height $(\mathrm{h} / 2)$ and providing double stiffeners at $\mathrm{h} / 3$ for the specimens respectively. The stiffeners ends are fully welded to inner side of the steel tube in the form of plus symbol as shown below.

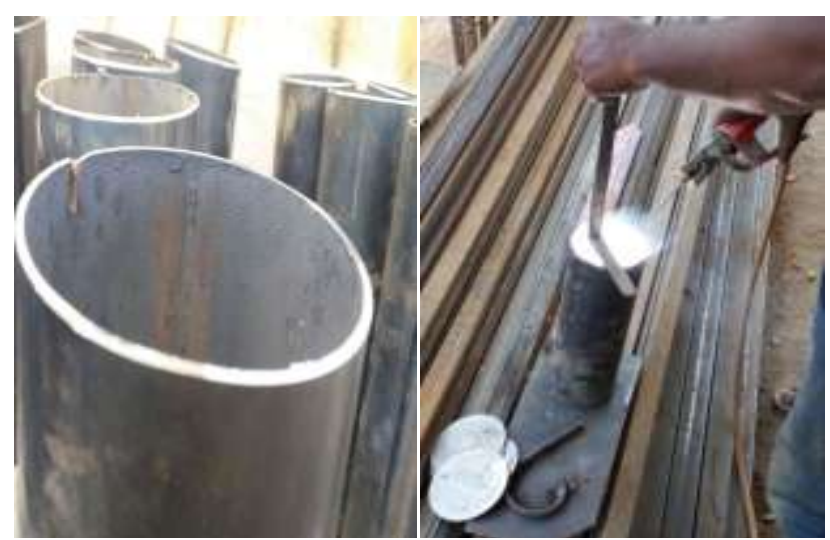

Fig-1: Machine cut steel tube and welding of stiffeners

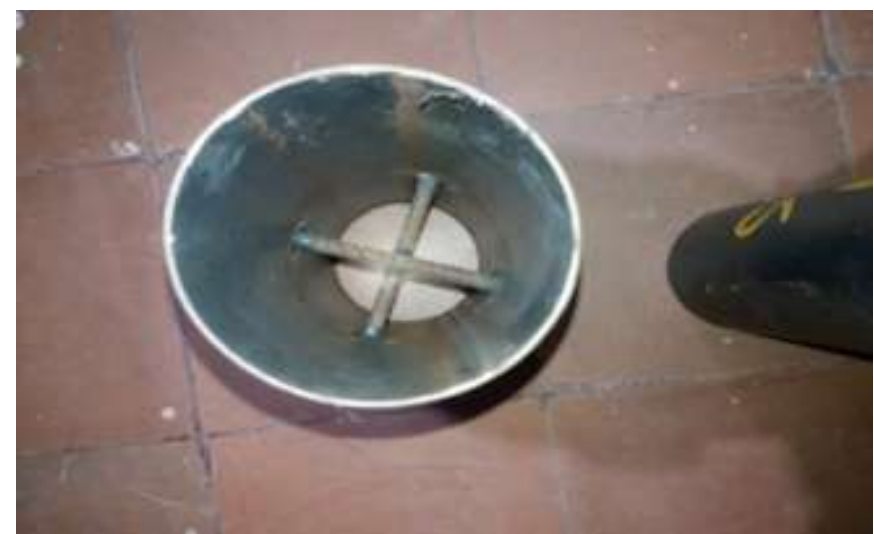

Fig-2: Single stiffened specimen

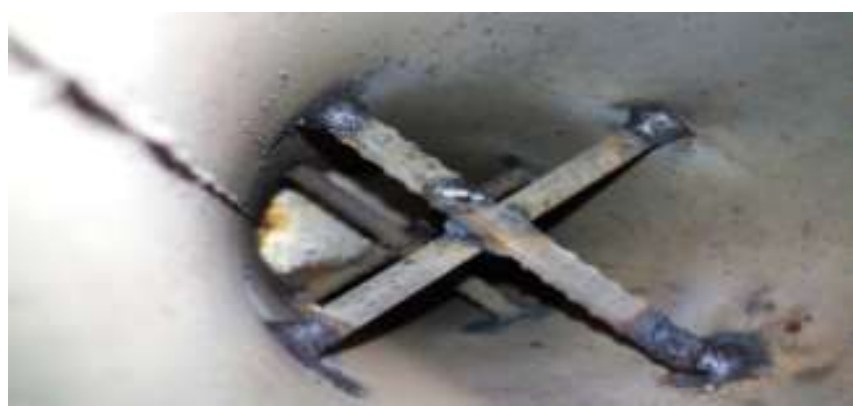

Fig-3: Double stiffened specimen

\section{EXPERIMENTAL PROGRAM}

\subsection{General}

In this work, mild steel tubes are used in preparation of the specimens which were manufactured in Karnataka, India. The steel tube sections were cut from the original $6 \mathrm{~m}$ steel tube and the ends machined to meet required length. The dimension of cross section is of $100 \mathrm{~mm}$ diameter with height of $300 \mathrm{~mm}$ and thickness of $2 \mathrm{~mm}$. The Stiffeners are used to strengthen the hollow steel tube columns and SCC filled steel tube columns. A total of 27 stub columns under monotonic compression load were tested in order to discover the best configuration of the stiffeners for confining column system (without or with stiffener at $h / 2 \&$ $h / 3$ of specimen respectively).

\subsection{Dimension of Tube}

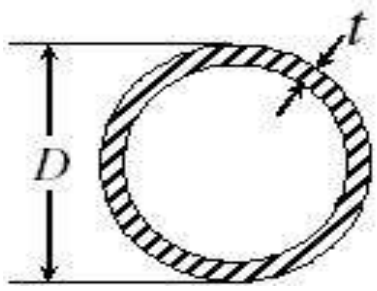

The dimension of the specimen is taken according to the limiting value of AISC 360-10.

$$
\mathrm{D} / \mathrm{t} \leq 0.31 \mathrm{E} / \mathrm{Fy}
$$




\subsection{Workability Tests on SCC}

Table 2: Workability tests on SCC

\begin{tabular}{|l|l|l|l|}
\hline Property & $\begin{array}{l}\text { Test } \\
\text { method }\end{array}$ & Unit & $\begin{array}{l}\text { Value } \\
\text { obtained }\end{array}$ \\
\hline Filling Ability & $\begin{array}{l}\text { Slump } \\
\text { Flow }\end{array}$ & $\mathrm{mm}$ & 670 \\
\hline $\begin{array}{l}\text { Passing } \\
\text { Ability }\end{array}$ & L-Box & H1/H2 & 0.9 \\
\hline $\begin{array}{l}\text { Segregation } \\
\text { Resistance }\end{array}$ & V-Funnel & Seconds & 10 \\
\hline
\end{tabular}

\subsection{Properties}

Table: 3 Properties of steel tube

\begin{tabular}{|l|l|l|l|}
\hline Sl.no & Description & symbol & value \\
\hline $\mathbf{1}$ & Yield strength & $\mathrm{F}_{\mathrm{y}}$ & $310 \mathrm{Mpa}$ \\
\hline $\mathbf{2}$ & Young's modulus & $\mathrm{E}_{\mathrm{s}}$ & $200 \mathrm{Gpa}$ \\
\hline $\mathbf{3}$ & Poisson ratio & $\mu$ & 0.3 \\
\hline $\mathbf{4}$ & Density & $\rho$ & $7800 \mathrm{Kg} / \mathrm{m}^{3}$ \\
\hline $\mathbf{5}$ & Diameter & $\mathrm{D}$ & $300 \mathrm{~mm}$ \\
\hline $\mathbf{6}$ & Height & $\mathrm{h}$ & $100 \mathrm{~mm}$ \\
\hline $\mathbf{7}$ & Thickness & $\mathrm{t}$ & $2 \mathrm{~mm}$ \\
\hline
\end{tabular}

Concrete type $\quad=\quad$ Triple blended SCC.

Pozzolonic material = Cement, Fly ash, GGBS.

Percentage of pozzolonic material:

Cement $=40 \%, \quad$ Fly ash $=30 \%, \quad$ GGBS $=30 \%$.

Aggregates size $\quad=\quad 12.5 \mathrm{~mm}$ down size.

Grade of concrete $=$ M50.

Proportion $\quad=1: 1.72: 1.6: 0.38$

(cementitious: Fine aggregate: Course aggregate: w/c)

Plasticize $\quad=\quad$ Glenium- B233 $(0.3 \%)$.

Stiffeners height:

Single stiffener $=h / 2 \quad \& \quad$ Double stiffeners $=h / 3$.

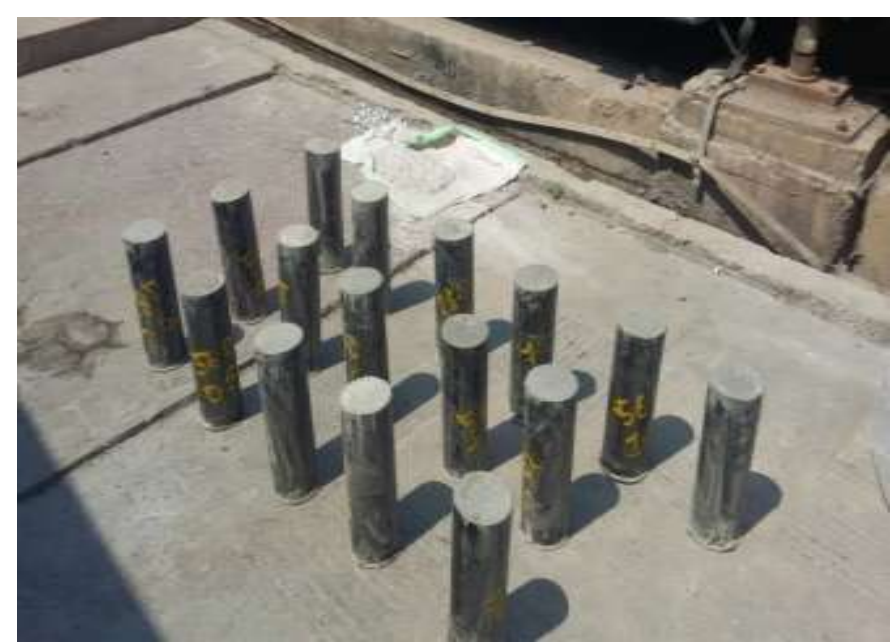

Fig-4: Casted specimens

\section{RESULTS}

After casting the composite concrete filled steel tubes they are cured and tested for 7days, 28days and 56 days using CTM of $2000 \mathrm{KN}$ capacity under loading rate of $40 \mathrm{KN}$ per minute. The deformation values through dial gauge are noted down at every $5 \mathrm{KN}$ interval until the specimen fails to carry the load. The load carrying capacity of unstiffened, single stiffened and double stiffened is shown in below tables

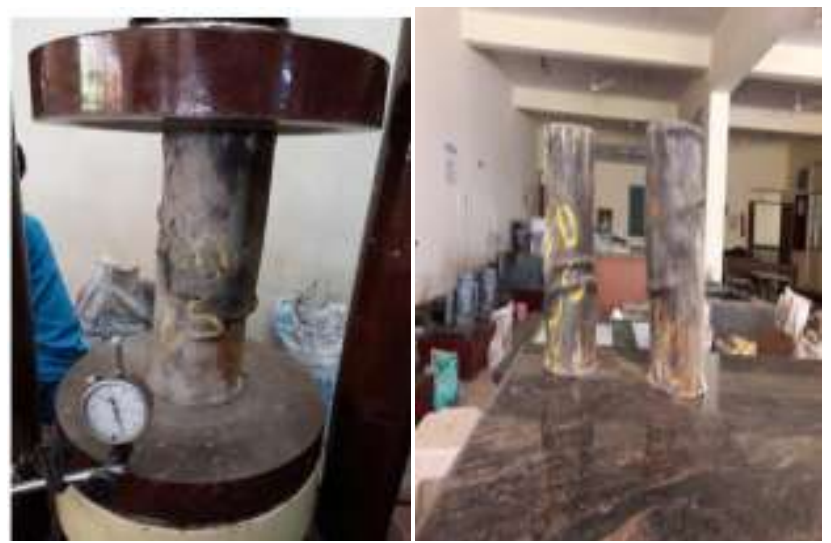

Fig-5: Testing of specimen using CTM \& Specimen after failure

Table 4: ultimate load carrying capacity

\begin{tabular}{|c|c|c|c|c|c|c|c|c|c|c|c|c|}
\hline & $\begin{array}{l}\text { Av } \\
\text { Ul } \\
\text { loa } \\
\text { KI }\end{array}$ & $\begin{array}{l}\text { era } \\
\text { time } \\
\text { d } \\
\text { d }\end{array}$ & in & $\begin{array}{l}\text { The } \\
\text { KN }\end{array}$ & eore & etica & 1 & Jltin & nat & 10 & & \\
\hline & & & & $\mathbf{A C}$ & & & & $\begin{array}{c}\text { itis } \\
\text { and } \\
540\end{array}$ & & & $\begin{array}{l}\text { Iro } \\
\text { de } \\
\text { de }\end{array}$ & \\
\hline & $n$ & $\stackrel{\sim}{\sim}$ & in & $N$ & జ్ & in & $N$ & $\underset{\sim}{\infty}$ & in & $N$ & 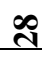 & in \\
\hline 巳్రి & da & & & & & & & & & & & \\
\hline $\begin{array}{l}\text { Hallow } \\
\text { zero } \\
\text { stiffened } \\
\end{array}$ & 15 & & & 154 & & & 15 & & & 15 & & \\
\hline $\begin{array}{l}\text { Hallow } \\
\text { single } \\
\text { stiffened }\end{array}$ & 20 & & & 154 & & & 15 & & & 15 & & \\
\hline $\begin{array}{l}\text { Hallow } \\
\text { double } \\
\text { stiffened }\end{array}$ & 21 & & & 154 & & & 15 & & & 15 & & \\
\hline $\begin{array}{l}\text { CFST } \\
\text { zero } \\
\text { stiffened } \\
\end{array}$ & $\ddot{g}$ & 吉 & $\frac{8}{6}$ & & & & & & & & & \\
\hline $\begin{array}{l}\text { CFST } \\
\text { single } \\
\text { stiffened }\end{array}$ & 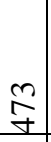 & $\frac{0}{6}$ & $\stackrel{0}{1}$ & & & & & & & & & \\
\hline $\begin{array}{l}\text { CFST } \\
\text { double } \\
\text { stiffened }\end{array}$ & 高 & 8 & 6 & రి & $\stackrel{0}{n}$ & 点 & $\frac{a}{m}$ & $\stackrel{n}{\forall}$ & 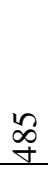 & o & n & 悉 \\
\hline
\end{tabular}




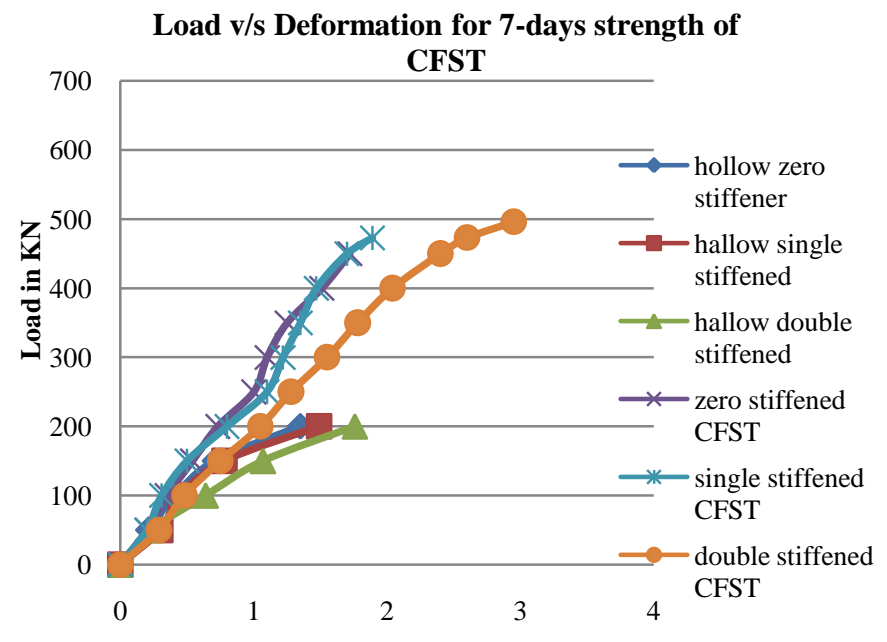

Deformation in $\mathbf{~ m m}$

Fig-6: Comparison of Load v/s deformation curve b/w HST and CFST for 7-days strength

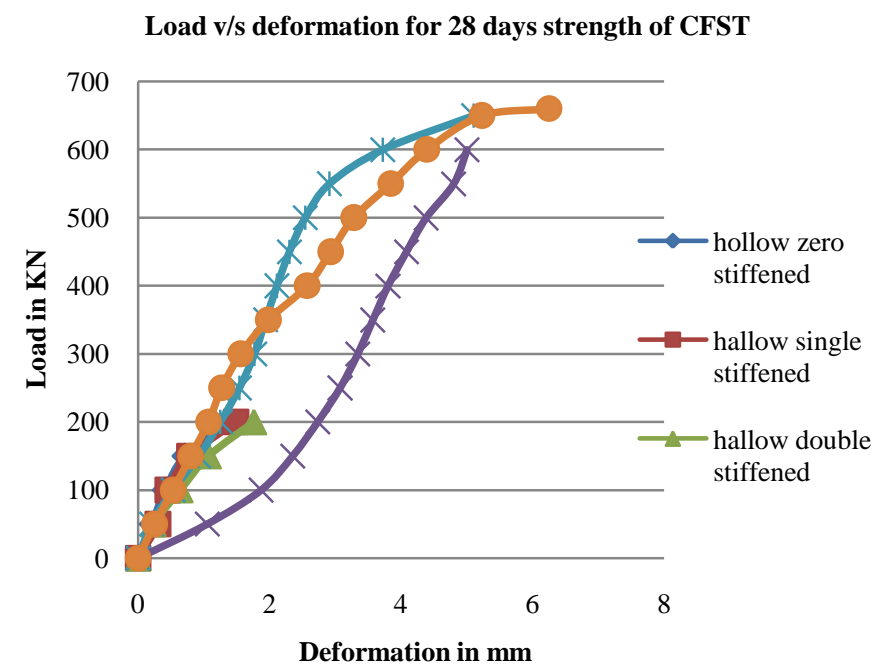

Fig-7: Comparison of Load v/s deformation curve b/w HST and CFST for 28-days strength

Load v/s deformation for 56 days strength of CFST

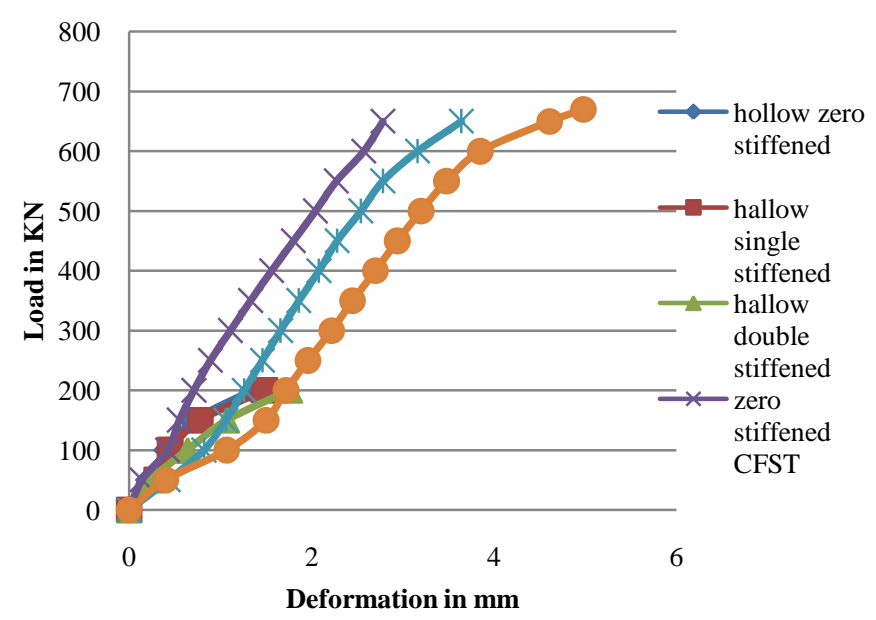

Fig-8: Comparison b/w HST and CFST for 56-days strength

\section{Comparison of 7-days ultimate load}

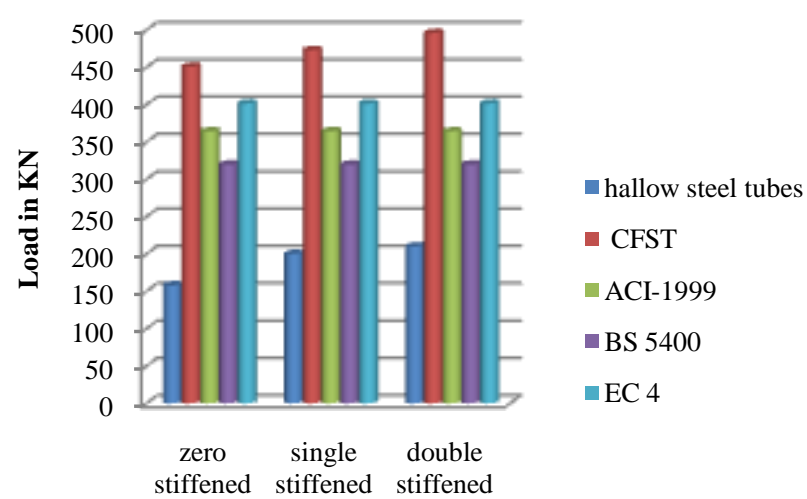

Number of stiffeners

Fig-9: Comparison of ultimate load b/w experimental \& theoretical values for 7-days strength

\section{Comparision of 28-days ultimate load}

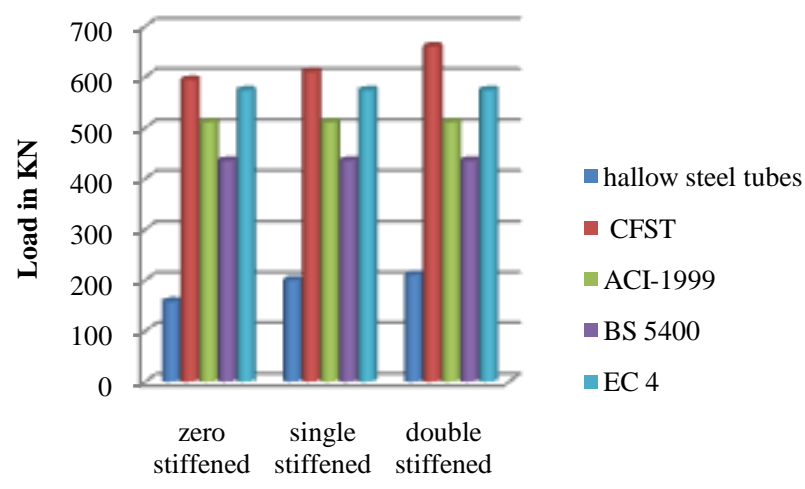

Number of stiffeners

Fig-10: Comparison of ultimate load b/w experimental \& theoretical values for 28-days strength

\section{Comparision of 56-days ultimate load}

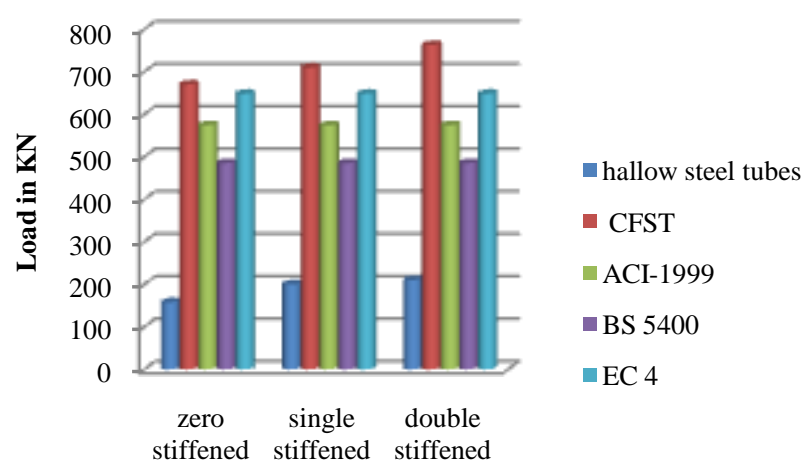

Number of stiffeners

Fig-11: Comparison of ultimate load b/w experimental \& theoretical values for 56-days strength 


\section{CONCLUSION}

1. Use of triple blended SCC as a filling component in steel tubes made the composite element to carry greater axial load compared to hollow steel tubes.

2. The workability of SCC is better because of increase in finer particles by use of triple blending (Cement, Fly ash, GGBS).

3. The load carrying capacity of stiffened specimens is more compared to unstiffened specimens.

4. The combination of double stiffeners at a height of $h / 3$ from the ends of CFST provided maximum load carrying capacity compared to single stiffened specimens and zero stiffened specimens.

5. Ultimate load of single stiffened CFST is more than that of the ultimate of zero stiffened CFST specimens.

6. The load carrying capacity increases as the strength of triple blended SCC increases.

7. Experimental ultimate load of CFST stiffened element is more compared to theoretical ultimate load from BS 4500, EC 4 and ACI code.

\section{ACKNOWLEDGEMENTS}

I am thankful to Mrs.Sharada S A and Dr.G Narayana for their guidance. I also thank department of civil engineering S J C institute of technology, chickallapura. And last but not the least my parents who have supported me to complete this project work.

\section{REFERENCES}

[1] P.Kiruthika1,

S.Balasubramanian, M.C.Sundarraja, J.Jegan "Strengthening of Concrete Filled Steel Tubular Columns using FRP Composites" International Journal of Innovative Research in Science, Engineering and Technology Vol. 4, Issue 4, April 2015.

[2] S. D. Bedage, Dr. D. N. Shinde "Comparative Study Of Concrete Filled Steel Tubes Under Axial Compression" International Journal Of Engineering Research Vol.3., Issue.3, 2015.

[3] Guochangli, Zhijian yang nad Yan lang "Experimental behavior of high strength concrete filed steel tubes under bi-axial eccentric loading" Advanced steel construction vol. 6, no. 4, pp. 963-975- 25 June 2010.

[4] Vishal V. Gore, Popat D. Kumbhar "Performance of Concrete Filled Steel Tube (CFST) Section International Journal of Science and Research" (IJSR) ISSN (Online): 2319-7064 Index Copernicus Value (2013): 6.14 | Impact Factor (2014): 5.611.

[5] Artiomas Kuranovas, Audronis Kazimieras Kvedaras, "Behavior of hollow concrete-filled steel tubular composite elements", Journal of civil engineering and management 2007, Vol XIII, No 2, 131-141.

[6] Athar Nihal, N.S Kumar “ Experimental Investigation on Monotonic Behavior of Circular Steel Stiffened Composite Column under Compression" Advances in Structural, Highways and CADD Engineering", 19th May 2015.
[7] Radhika. K.S, Baskar. K "Bond stress characteristics on circular concrete filled steel tubular columns are using mineral admixture metakaoline" International journal of civil and structural engineering volume 3, no 1, 2012.

[8] Krishna Murthy.N, Narasimha Rao A.V, Ramana Reddy I .Vand, Vijaya sekhar "Mix Design Procedure for Self Compacting Concrete" IOSR Journal of Engineering (IOSRJEN) e-ISSN: 22503021, p-ISSN: 2278-8719, www.iosrjen.org Volume 2, Issue 9 (September 2012), PP 33-41.

[9] Tao, Z., Han, L. H., and Wang, Z. B. "Experimental behaviors of stiffened concrete-filled thin-walled hollow steel structural (HSS) stub columns." Journal of Constructional Steel Research, 61, pp. 962-983.

[10] Mr.Ankit J. Patel, Mr.Dixitkumar D. Patel "SelfCompacting Concrete with Use of Waste Material" International Journal For Technological Research In Engineering Volume 1, Issue 9, May-2014

[11] Qing Quan Liang1, Brian Uy2, J. Y. Richard Liew," Strength of concrete-filled steel box columns with local buckling effects", Australian Structural Engineering Conference11-14 September, 2005, Newcastle, Australia.

[12] Biswadeep Bharali," Experimental study on self compacting concrete (SCC) using GGBS and fly ash" International Journal of Core Engineering \& Management (IJCEM) Volume 2, Issue 6, September 2015.

[13] Elremaily A, Azizinamini A. "Behavior and strength of circular concrete-filled tube columns". Journal of Constructional Steel Research 2002; 58(12):1567-91.

[14] Hajjar J. "Concrete-filled steel tube columns under earthquake loads". J. Progress Strut. Engng Mater. 2000;2(1):1-10.

[15] E K Mohanraj*, S Kandasamy, A Rajaraman," Behavior of concrete filled steel tubular columns", 35 thConference on our world in concrete \& structures: 25 - 27 August 2010, Singapore.

\section{BIOGRAPHY}

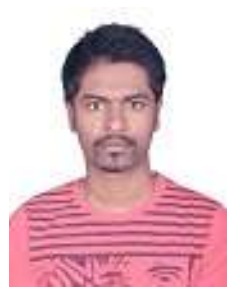

NAVEEN KUMAR Y R Obtained B.E degree in Civil Engineering (First class with distinction) during the year 2014 from S J C Institute of Engineering chickballapur Affiliated to VTU Belgaum. Presently perusing Master of Technology in Structural Engineering at S J C Institute of Engineering 